\title{
PENGARUH INOKULASI KAPANG PADA FERMENTASI KATSUOBUSHI CAKALANG (Katsuwonus pelamis)
}

\author{
Jamal Basmal"), Umi Rahayu"), dan Suyuti Nasran")
}

\begin{abstract}
ABSTRAK
Percobaan pembuatan katsuobushi cakalang (Katsuwonus pelamis) dengan menginokulasikan jenis-jenis kapang Eurotium repens, E. chevalieri dan kombinasi kedua kapang ini telah dilakukan dengan cara menyemprotkan ke permukaan arabushi. Tahapan fermentasi dilakukan sebanyak tiga tahap dan setiap tahap fermentasi dihentikan bila warna kapang telah berubah dari warna putih menjadi hijau keabu-abuan atau abu-abu. Sedangkan untuk meningkatkan kelembaban ruangan fermentasi diletakkan sebanyak $10 \mathrm{~g}$ lembaran kapas yang dibasahi dengan air sebanyak $13,5 \%$ (b/v) dari bobot loin arabushi. Hasil percobaan menunjukkan terjadinya peningkatan kadar air, nilai $a_{w}$ dan penurunan kadar fenol selama fermentasi. Nilai $\mathrm{pH}$ meningkat hingga fermentasi tahap dua dan kemudian menurun untuk semua perlakuan, kecuali perlakuan kontrol. Perlakuan inokulasi kombinasi E. repens dan E. chevalieri mampu meningkatkan proses degradasi protein menjadi sejumlah asam-asam amino dibandingkan pada inokulasi monokultur maupun kontrol. Jumlah asam amino yang terbentuk setelah fermentasi tahap ketiga pada perlakuan kombinasi adalah sebesar $90,07 \%$, perlakuan monokultur $E$. repens sebesar $22,73 \%$, perlakuan monokultur E. chevalieri sebesar $74,49 \%$, dan kontrol sebesar $56,49 \%$. Terjadi penurunan nilai aroma dan rasa filtrat katsuobushi selama tahapan fermentasi dan nilai tertinggi setelah fermentasi tahap ketiga ditemukan pada perlakuan kombinasi untuk aroma sebesar 3,4 dan rasa sebesar 3,75 .
\end{abstract}

\section{ABSTRACT: Effect of mould inoculation on dried fish stick (katsuobushi) of skipjack (Katsuwonus pelamis). By: Jamal Basmal, Umi Rahayu, and Suyuti Nasran}

\begin{abstract}
An experiment to produce dried fish stick (katsuobushi) from skipjack, using starter culture of Eurotium repens, E. chevalieri, and their combinations, was carried out. Moulds were inoculated by streching them out on the surface of arabushi for each treatment. Fermentation carried out in three steps. Every step of fermentation was stopped when the moulds colour changed from white to greenish grays or grays. The relative humidity of fermentation chamber was maintained by putting chamber of $10 \mathrm{~g}$ moistened cotton at the bottoms of fermentation chamber. The moistened cotton was prepared by adding moitened cotton with tap water $13.5 \%(\mathrm{~W} / \mathrm{V})$ of the weight of arabushi every step of fermentation. Results showed that an increase of moisture content and $a_{w}$-value, and a decrease of phenol content were observed during fermentation. $\mathrm{pH}$ value increased up to the second fermentation process, except for control which continuously increasing. Amino acids formed due to protein degradation by combination culture of $E$. repens and $E$. chevalieri, monoculture of E. repens, monoculture of E. chevalieri, and control were $90.07 \%$, $74.49 \%, 22.73 \%$, and $56.49 \%$ respectively. Aroma and taste scores of katsuobushi filtrate decreased during fermentation. The highest scores of aroma and taste of the katsuobushi filtrate were found in the product inoculated with the combination of E. repens and E. chevalieri i.e. 3.4 and 3.75 , respectively.
\end{abstract}

\section{KEYWORDS: mould innoculation, dried fish stick, fermentation, katsuobushi}

\section{PENDAHULUAN}

Katsuobushi adalah suatu produk perikanan yang diolah secara tradisional menggunakan jenis-jenis kapang spesifik pada kondisi suhu dan tingkat kelembaban nisbi udara relatif tinggi di dalam wadah tertutup. Sjef van Eys (1983) membagi kualitas katsuobushi berdasarkan jumlah fermentasi yang dilakukan yakni arabushi yaitu ikan asap kering yang belum dilakukan proses fermentasi tetapi telah mengalami beberapa tahapan proses seperti proses perebusan, pengeringan dan pengasapan. Biasanya jenis produk ini disajikan dalam bentuk komponen dasar sliced fushi (kezuri-bushi); Hadaka-bushi adalah produk arabushiyang telah mengalami proses perbaikan penanganan dan penampakan produk; Arashiage-bushi adalah produk hadaka-bushi yang telah mengalami dua hingga tiga kali proses fermentasi menggunakan kapang spesifik; dan shiage-bushi merupakan produk arashiage-bushi yang telah mengalami perbaikan penanganan yang siap dipasarkan.

\footnotetext{
-) Peneliti pada Pusat Riset Pengolahan Produk dan Sosial Ekonomi Kelautan dan Perikanan
} 
Berbagai jenis ikan dapat diolah menjadi katsuobushi seperti ikan pelagik besar yang meliputi: ikan tuna, ikan cakalang (Katsuwonus pelamis), dan ikan tongkol (Euthynus affinis, dan Auxis thazard). Sedangkan dari ikan pelagik kecil adalah ikan lemuru (Sardinella sp.), ikan layang (Decapterus sp.), dan jenis-jenis lainnya yang mempunyai kadar lemak di bawah 3\% (Tanikawa et al., 1985).

Indonesia sebagai negara beriklim tropis mempunyai tingkat kelembaban relatif tinggi dan suhu yang sesuai untuk memberdayakan pertumbuhan kapang. Diketahui bahwa berbagai jenis kapang tumbuh baik pada permukaan produk semi kering seperti biji-bijian kering dan berbagai macam produk perikanan kering (ikan asin dan pindang). Dalam pengolahan arabushi menjadi katsuobushi tidak semua jenis kapang dikehendaki tumbuh, karena beberapa jenis kapang dapat memproduksi mikotoksin selama proses fermentasi. Tanikawa (1985) dan Doi et al. (1989a \& 1989b) hanya kelompok Aspergillus glaucus seperti E. repens dan E. chevalieri yang dibiarkan tumbuh pada permukaan arasbuhi. Selanjutnya Doi et al. (1989a; 1990) melaporkan bahwa $E$. repens selama proses fermentasi arabushi mampu mendegradasi protein menjadi peptida sederhana dan fenol menjadi produk turunannya (O-metilasi) yang akan menciptakan citarasa spesifik ikan kayu. Hanafiah et al. (1984), Basmal et al. (1998), dan Giyatmi (1998) menyatakan bahwa jenis kapang yang dapat berasosiasi dengan kelompok $A$. glaucus selama proses fermentasi adalah A. flavoviridscens, Torula sp., Cladosporium herbarium, Catenlaria fliginea, Aspergillus sp., dan Penicillium sp. Teknologi yang mungkin dapat diterapkan untuk menghambat berasosiasinya kapang yang tidak diinginkan tumbuh selama proses fermentasi adalah dengan mengatur kadar air dan nilai $\mathrm{a}_{\mathrm{w}}$ arabushi serta mengontrol tingkat kelembaban relatif udara ruangan fermentasi.

Diduga bahwa masing-masing kapang mempunyai kemampuan yang berbeda untuk tumbuh pada permukaan substrat. Adanya perbedaan kemampuan tumbuh ini tidak terlepas dari faktor eksternal seperti perubahan suhu udara, tingkat kelembaban, ketersediaan oksigen dan tekanan parsial antara substrat dan udara luar. Selain itu juga dipengaruhi oleh faktor internal yang meliputi kondisi substrat, seperti kadar air, nilai $a_{w}$, dan ketersediaan nutrisi substrat. Pada ikan kayu (arabushi) kapang dapat tumbuh secara individual (soliter) atau hidup bersama saling menguntungkan (simbiose mutualistis) dengan memanfaatkan hasil metabolik kapang yang satu untuk menunjang pertumbuhan kapang yang lainnya. Di Jepang pengolahan arabushi menjadi katsuobushi pada umumnya menggunakan dua jenis atau lebih kapang sekaligus agar hasil yang diperoleh mencapai maksimal. Hasil isolasi kapang dari katsuobushi buatan Jepang ditemukan dua jenis kapang yakni $A$. tonophilus dan Penicillium citrinum, sedangkan hasil penelitian Jamal et al. (1998) menemukan bahwa fermentasi arabushi secara monokultur memberikan hasil yang kurang memuaskan.

Tujuan penelitian ini adalah untuk mengetahui pengaruh jenis kapang monokultur maupun kombinasi antara dua jenis kapang terhadap kualitas katsuobushi yang dihasilkan.

\section{BAHAN DAN METODE}

\section{Bahan}

Jenis ikan yang digunakan dalam penelitian ini adalah ikan cakalang (Katsuwonus pelamis) berukuran antara 2,5 kg/ekor - 3,0 kg/ekor. Ikan-ikan ini diperoleh dari nelayan Pelabuhan Ratu yang ditangkap menggunakan jaring payang dengan lama penangkapan tidak lebih dari enam jam. Kondisi ikan masih dalam keadaan segar (rigor), mata cerah, insang merah, dan berbau rumput laut segar, tekstur daging kompak dan belum terlihat adanya pemisahan antara lapisan daging, penampakan ikan cerah spesifik ikan cakalang, dan bagian perut tidak pecah. Ikan ini kemudian dies menggunakan es balok yang telah dihancurkan dengan perbandingan ikan berbanding es hancuran (es curah) 1: 1, kemudian dibawa ke Pusat Riset Pengolahan Produk dan Sosial Ekonomi Kelautan dan Perikanan untuk diproses lebih lanjut. Sedangkan arang dan batok kelapa digunakan sebagai sumber asap dan energi panas.

Wadah yang digunakan untuk inokulasi kapang pada permukaan arabushi cakalang adalah kotak kayu berukuran $30 \times 30 \times 30 \mathrm{~cm}^{3}$. Sedangkan jenis kapang yang digunakan untuk penelitian monokultur adalah Eurotium repens dan E. chevalieri dan untuk kombinasi telah digunakan campuran antara kapang E. repens dan E. chevalieri yang berasal dari isolasi penelitian pendahuluan.

\section{Metode}

Ikan cakalang segar diolah menjadi arabushi menggunakan metode yang telah dikembangkan oleh Nasran \& Irianto (1987) dengan sedikit modifikasi, yakni dibuang kepala dan isi perut, kemudian difilet, direbus selama 90 menit pada suhu antara $80^{\circ} \mathrm{C}$ $90^{\circ} \mathrm{C}$, didinginkan pada suhu kamar kemudian dibelah menjadi empat loin yang biasa disebut dengan hon-bushi cakalang. Untuk selanjutnya dilakukan kombinasi pengasapan dan pengeringan selama enam jam/hari dengan diselang satu hari tidak dilakukan kombinasi pengasapan dan pengeringan, setiap 
harinya enam jam hingga mencapai kadar air 17\% $20 \%$ bobot basah

Fermentasi arabushi dilakukan dalam kotak kayu berukuran $30 \times 30 \times 30 \mathrm{~cm}^{3}$ dengan cara arabushi dilembabkan selama satu malam kemudian disusun di atas rak-rak yang telah disediakan di dalam kotak kayu secara bersilangan. Untuk meningkatkan derajat kelembaban di dalam kotak kayu telah diletakkan 10 g kapas yang dibasahi dengan air sebanyak 13,5\% (b/v) dari bobot arabushi yang difermentasikan, dan setiap 4 hari sekali dilakukan perubahan susunan arabushi dengan tujuan untuk menghindari terjadinya tingkat kelembaban yang berlebihan pada susunan arabushiyang paling bawah. Di samping itu juga untuk menghindari jangan sampai terjadi udara jenuh di dalam ruangan fermentasi. Penelitian dilakukan dengan rancangan acak lengkap faktorial $(4 \times 3)$ dengan dua kali ulangan. Faktor pertama terdiri atas empat jenis kapang: a. Eurotium chevalieri (EC), b. E. repens $(E R), c$. Kombinasi E. chevalieri dengan E. repens (ECR), dan d. Kontrol (K). Faktor kedua tahapan fermentasi: Fermentasi I, II, dan III. Lama untuk setiap tahap fermentasi tersebut adalah 10, 8, dan 20 hari. Penetapan lama fermentasi didasarkan pada kecepatan perubahan kapang dari warna putih menjadi hijau keabu-abuan atau abu-abu (Tanikawa, 1985). Sebelum fermentasi, kapang yang tumbuh di permukaan arabushi dihilangkan dengan cara dijemur selama 1-2 jam di bawah sinar matahari dan kemudian disikat hingga bersih. Produk yang telah bersih tersebut kemudian diinokulasikan dengan kapang

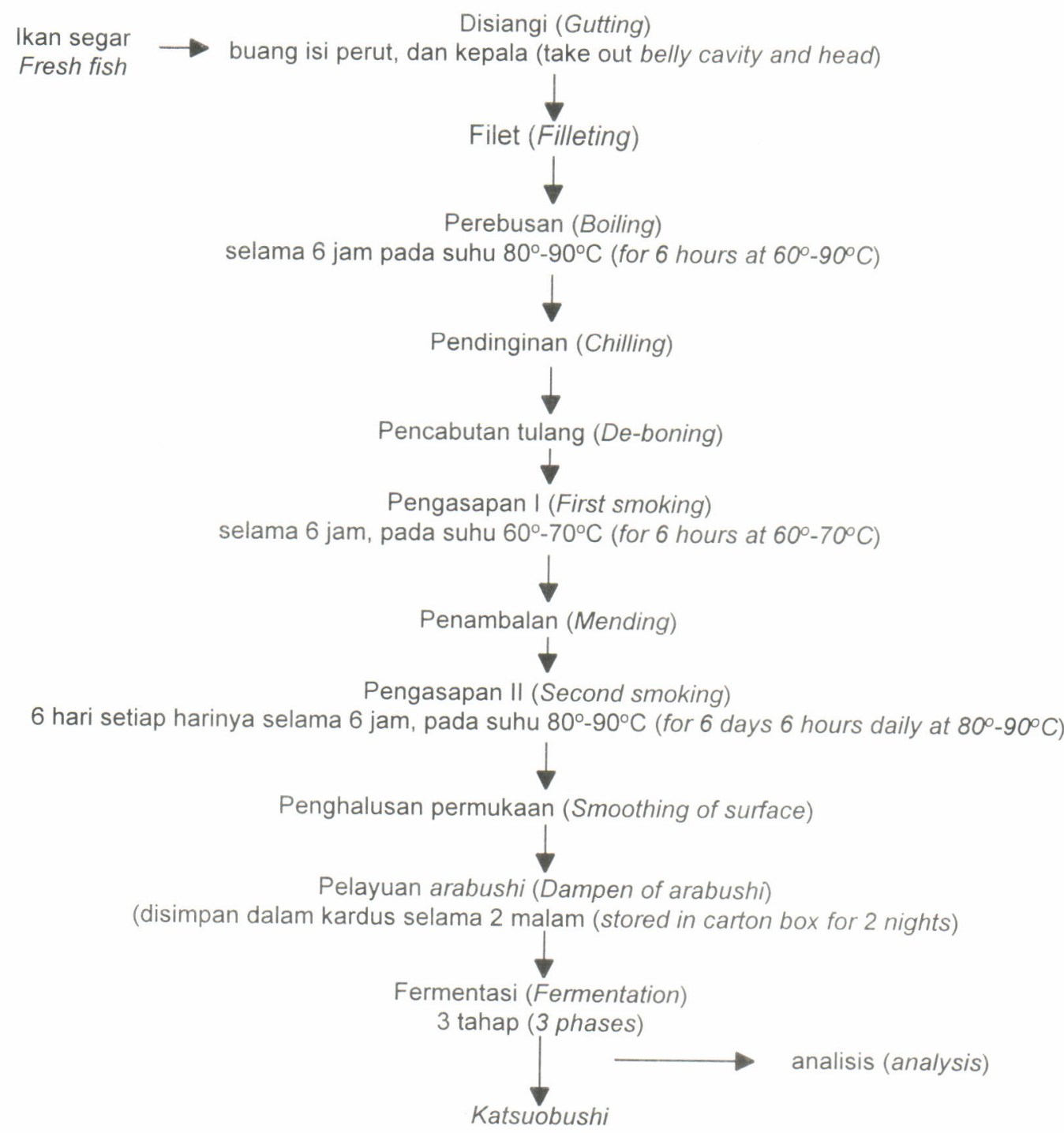

Gambar 1. Diagram pembuatan katsuobushi

Figure 1. Diagram of katsuobushi production 
yang sesuai dengan perlakuan. Diagram pembuatan katsuobushi dapat dilihat pada Gambar 1.

Pada setiap akhir tahap fermentasi dilakukan analisis yang meliputi pengujian kadar air, nilai $\mathrm{pH}$ filtrat katsuobushi, dan kadar fenol menggunakan metode AOAC (1980). Nilai $a_{w}$ ditentukan menggunakan $a_{w}$-meter, jenis kapang yang tumbuh diidentifikasi menggunakan metode Piit \& Hocking (1985) dan Samson et al. (1995). Kandungan asam amino ditentukan dengan menggunakan HPLC (High Performance Liquid Chromatographi) merek Shimadzu DU-Point high performance pressure liquid chromatography LC-A, jenis coulomn ISC-07/S1504 dengan detector fluoresence detector FLD-1, sedangkan nilai organoleptik telah diuji aroma, rasa, dan penerimaan umum filtrat katsuobushi menggunakan metode Sakakibara et al. (1990).

\section{HASIL DAN BAHASAN}

\section{Perubahan kadar air}

Tahapan fermentasi berpengaruh sangat nyata terhadap perubahan kadar air. Penelitian menunjukkan bahwa peningkatan kadar air maksimal terjadi selama fermentasi tahap II, kecuali perlakuan ECR hingga akhir fermentasi masih terjadi peningkatan kadar air produk. Terjadinya peningkatan kadar air pada masing-masing perlakuan mungkin disebabkan sejumlah air yang diletakkan pada dasar kotak terserap ke produk selama proses fermentasi. Adanya perbedaan penyerapan uap air ke dalam arabushi sangat tergantung pada faktor eksternal seperti perubahan kelembaban relatif udara, suhu udara, perbedaan tekanan parsial, sifat fisik arabushi, dan jenis kapang. Terbukti meskipun jumlah air yang diberikan sama, tetapi yang diserap ke produk adalah berbeda karena setiap jenis kapang yang diinokulasikan pada permukaan arabushimempunyai kebutuhan air yang berbeda untuk kelangsungan tumbuhnya. Pada Gambar 2 dapat dilihat perubahan kadar air selama proses fermentasi dan ternyata jumlah air yang diperlukan lebih banyak ditemukan pada perlakuan EC dibandingkan perlakuan ER. Akan tetapi bila arabushi difermentasikan menggunakan kombinasi antara E. repens dan E. chevalieri (ECR) terjadi peningkatan kadar air selama tahapan fermentasi dan mencapai maksimal pada fermentasi tahap III yakni sebesar 30,9\% bk (bobot kering)

Hasil perhitungan ditemukan jumlah air yang diserap setelah fermentasi tahap dua berturut-turut untuk perlakuan $\mathrm{ER}=6,5 \% \mathrm{bk} ; \mathrm{EC}=7,1 \% \mathrm{bk}$; dan $\mathrm{ECR}=7,7 \%$ bk. Memasuki tahap III fermentasi terjadi penurunan kadar air produk untuk semua perlakuan kecuali perlakuan ECR meningkat sebesar 2,9\% bk. Perbedaan fluktuasi kadar air produk kemungkinan tidak hanya disebabkan oleh faktor eksternal tetapi juga oleh perbedaan jenis kapang dan kecepatan tumbuhnya selama fermentasi tahap I dan II. Hasil perhitungan dari fermentasi tahap II ke tahap III ditemukan penurunan kadar air pada perlakuan $\mathrm{ER}=$ $3,3 \%$ bk; $E C=1,9 \%$ bk. Hasil tersebut membuktikan bahwa penggunaan $E$. repens untuk memfermentasikan arabushi menyebabkan kadar air produk lebih tidak stabil dibandingkan arabushi yang difermentasikan menggunakan E. chevalierimaupun

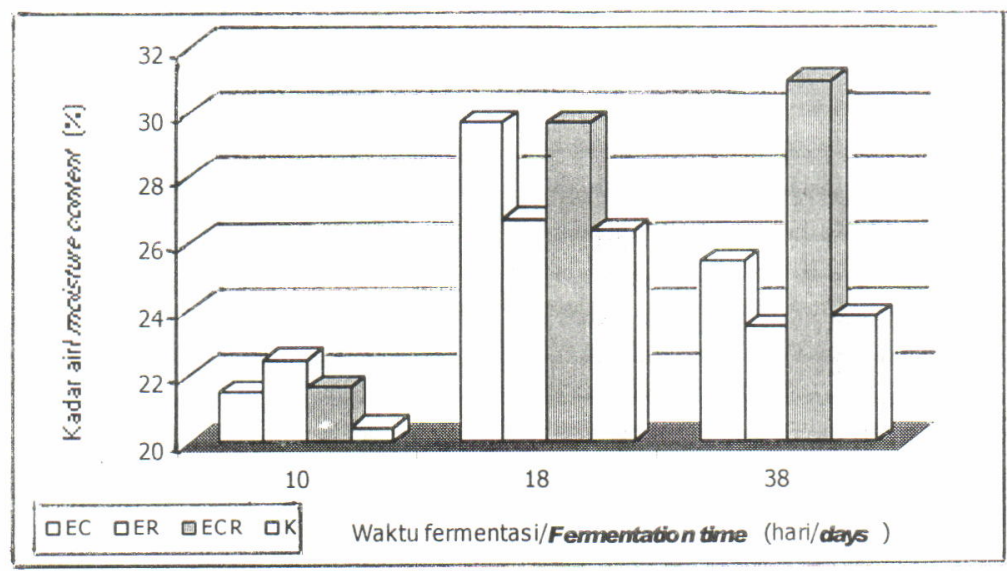

EC = perlakuan inokulasi kapang $E$. chevalieri (innoculation of E. chevalieri)

ER = perlakuan inokulasi kapang $E$. repens (innoculation of $E$. repens)

ECR = inokulasi kombinasi antara E. repens dan E. chevalieri (innoculation of combination between $E$. repens and $E$. chevalieri)

$\mathrm{K} \quad=\operatorname{kontrol}($ control)

Gambar 2. Perubahan kadar air ikan kayu selama proses fermentasi

Figure 2. Fluctuation of moisture content of katsuobushi during fermentation process 
kombinasi keduanya. Rendahnya kadar air percobaan perlakuan ER dapat menekan pertumbuhan bakteri pembusuk. Sebaliknya pada perlakuan ECR produk menjadi lembab dan mengeluarkan bau amoniak agak tajam, tetapi setelah dijemur di bawah sinar matahari bau amoniak tersebut hilang.

\section{Perubahan nilai $a_{w}$}

Faktor yang sangat berpengaruh terhadap kecepatan laju pertumbuhan kapang adalah nilai $\mathrm{a}_{\mathrm{w}}$ suhu, oksigen, dan ketersediaan nitrogen (Samson et al., 1995). Hasil pengukuran nilai $a_{w}$ pada semua perlakuan berkisar antara $0,77-0,89$, sedangkan nilai $a_{w}$ minimal untuk tumbuh $E$. repens dan $E$. chevalieri berkisar antara 0,71-0,74 dengan temperatur maksimum antara $28^{\circ} \mathrm{C}-30^{\circ} \mathrm{C}$ (Samson et al., 1995). Berdasarkan pernyataan ini berarti $E$. repens dan $E$. chevalieri yang diinokulasikan pada permukaan arabushi mampu tumbuh selama proses fermentasi.

Hasil percobaan menunjukkan bahwa tahapan proses fermentasi berpengaruh terhadap perubahan nilai $a_{w}$. Peningkatan nilai $a_{w}$ tertinggi ditemukan pada fermentasi tahap III yakni sebesar 0,85 kemudian diikuti berturut-turut oleh fermentasi tahap II sebesar 0,84 dan fermentasi tahap I sebesar 0,79. Terjadinya kecenderungan peningkatan ini disebabkan selama fermentasi telah terjadi suatu proses keseimbangan antara nilai $a_{w}$ produk dengan tingkat kelembaban ruangan fermentasi.

Hasil pencatatan tingkat kelembaban ruangan fermentasi berkisar antara $85 \%-90 \%$, sedangkan nilai $a_{w}$ arabushi sebesar 0,75 . Dengan adanya selisih perbedaan tersebut kemungkinan akan menyebabkan terjadinya perpindahan massa air dari ruangan fermentasi ke produk. Diketahui bahwa kapang akan tumbuh subur bila nilai $a_{w}$ sesuai dengan pertumbuhan optimum kapang, dalam hal ini pada fermentasi tahap I pertumbuhan kapang agak lambat dan ini terlihat dengan kecilnya perubahan nilai $a_{w}$ dari arabushi ke fermentasi tahap pertama sebesar 0,04. Pada fermentasi tahap II pertumbuhan kapang lebih subur dan ini terlihat dengan cepatnya permukaan produk ditutupi oleh kapang dengan hipha panjang-panjang seperti kapas. Diduga pada fermentasi tahap II ini nilai $a_{w}$ telah sesuai dengan pertumbuhan optimum kapang.

Inokulasi kapang pada permukaan arabushi berpengaruh sangat nyata terhadap perubahan nilai $a_{w}$. Nilai $a_{w}$ tertinggi pada akhir fermentasi tahap III ditemukan pada perlakuan ECR dan berpengaruh sangat nyata terhadap perlakuan (K), (EC), dan (ER). Perlakuan EC dan ER tidak berpengaruh nyata pada akhir fermentasi tahap III. Dari hasil analisis terbukti bahwa kemampuan tiap jenis kapang untuk meningkatkan nilai $\mathrm{a}_{\mathrm{w}}$ adalah berbeda sesuai dengan kebutuhan pertumbuhannya. Perlakuan kombinasi (ECR) membutuhkan nilai $a_{w}$ yang cukup tinggi sebagai persyaratan untuk pertumbuhan kapang pada permukaan produk. Oleh sebab itu sejumlah uap air di dalam ruangan fermentasi lebih banyak diserap dibandingkan dengan perlakuan EC dan ER. Pada Gambar 3 dapat dilihat perubahan nilai $a_{w}$ produk

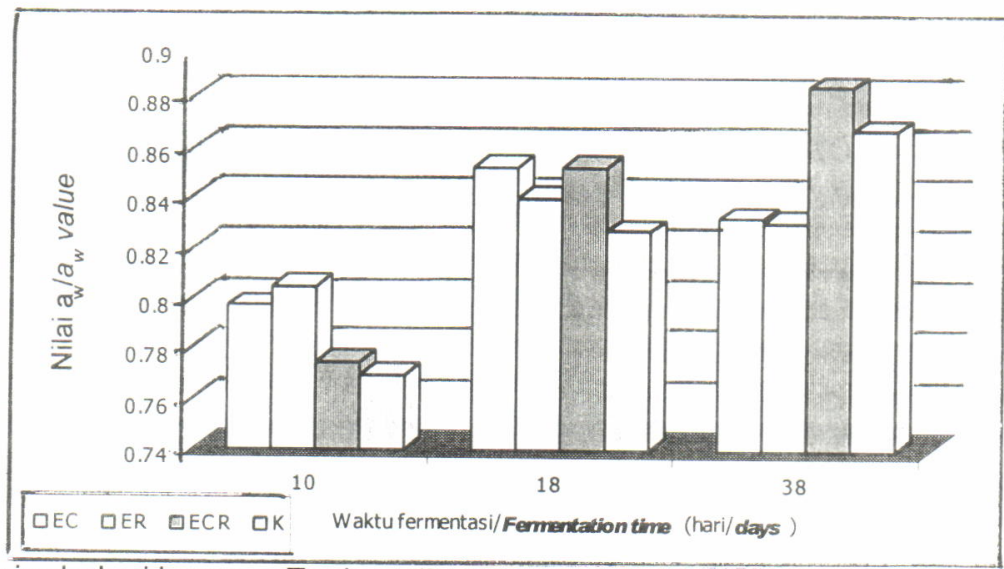

$\mathrm{EC}$ = perlakuan inokulasi kapang $E$. chevalieri (innoculation of $E$. chevalieri)

$\mathrm{ER}$ = perlakuan inokulasi kapang $E$. repens (innoculation of E. repens)

$E C R$ = inokulasi kombinasi antara $E$. repens dan $E$. chevalieri (innoculation of combination between $E$. repens and E. chevalieri)

$\mathrm{K}=\operatorname{kontrol}$ (control)

Gambar 3. Perubahan kadar fenol katsuobushi selama fermentasi

Figure 3. Change of phenol content of katsuobushi during fermentation process 


\section{PERUBAHAN KADAR FENOL}

Akumulasi asap pada arabushi sangat tergantung pada kualitas bahan bakar, tingkat kelembaban ruangan asap, suhu, dan kecepatan penarikan air dari dalam daging ikan selama proses kombinasi pengeringan dan pengasapan. Komposisi asap yang terserap ke dalam daging ikan diperkirakan lebih dari 200 macam komponen, di antaranya adalah fenol yang berfungsi selain sebagai antioksidan dan bakteriosidal juga sebagai komponen dasar pembentukan citarasa dan aroma ikan asap (Wheaton \& Lawson, 1985). Hasil analisis kadar asap pada ikan cakalang setelah diasapi ditemukan sebesar $4,9 \%$. Fenol yang telah terperangkap dalam arabushi akan didegradasi menjadi produk turunannya selama proses fermentasi berlangsung. Menurut Doi et al. (1989a, b) kapang Aspergillus repens MA0197 mampu mendegradasi kadar fenol membentuk citarasa spesifik katsuobushi. Kecepatan degradasi fenol menjadi produk turunannya sangat dipengaruhi oleh jenis kapang, suhu, tingkat kelembaban udara ruangan fermentasi, kadar air, dan nilai $a_{w}$ produk yang akan difermentasikan. perlakuan EC, ER, dan K (Kontrol). Fenol tersisa setelah fermentasi tahap pertama untuk semua perlakuan adalah berkisar antara 3,2\%-3,7\% bb (bobot basah). Pada fermentasi tahap II, kadar fenol tersisa berkisar antara 2,5\%-2,9\% dengan kadar fenol terendah ditemukan pada perlakuan ECR $(2,5 \%)$ dan tertinggi pada perlakuan EC $(2,9 \%)$. Kadar fenol dari perlakuan ECR berbeda nyata dengan perlakuan ER, K, dan EC. Pada akhir fermentasi tahap III, kadar fenol terendah ditemukan pada perlakuan $\mathrm{K}$ (kontrol) yakni sebesar $1,59 \%$. Kadar fenol tersebut tidak berbeda nyata dibandingkan dengan perlakuan ECR $(1,63 \%)$, tetapi berbeda nyata dengan perlakuan EC dan ECR. Menurut Doi et al. (1989b) dan Sakakibara et al. (1990) penurunan kadar fenol oleh kapang menguntungkan sebab akan menimbulkan aroma dan rasa spesifik katsuobushi. Kombinasi E. repens dan E. chevalieri menunjukkan aktivitas yang lebih tinggi di dalam mendegradasi fenol menjadi produk turunannya (Gambar 4). Bau asap merupakan ciri katsuobushi dan rasa sepat (punget) akibat pengaruh asap akan berkurang (moderat) setelah dilakukan beberapa kali proses fermentasi menggunakan jenis

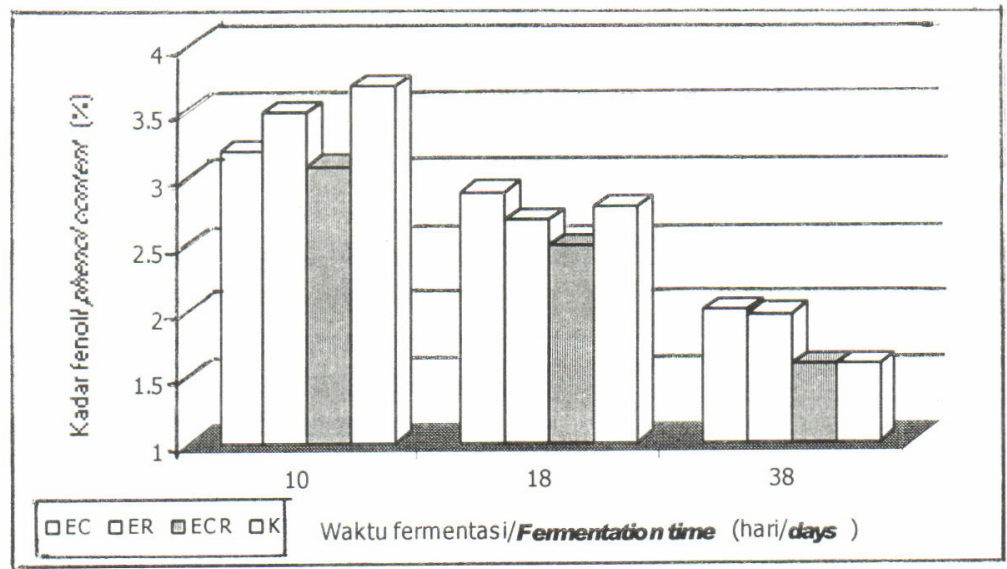

$E C=$ perlakuan inokulasi kapang $E$. chevalieri (innoculation of $E$. chevalieri)

$E R$ = perlakuan inokulasi kapang $E$. repens (innoculation of $E$. repens)

$E C R=$ inokulasi kombinasi antara $E$. repens dan E. chevalieri (innoculation of combination between $E$. repens and $E$. chevalieri)

$\mathrm{K} \quad=\operatorname{kontrol}$ (control)

Gambar 4. Perubahan kadar fenol katsuobushi selama fermentasi

Figure 4. Change of phenol content of katsuobushi during fermentation process

Hasil fermentasi menunjukkan bahwa jenis kapang dan waktu fermentasi berpengaruh nyata terhadap penurunan kadar fenol produk. Pada fermentasi tahap pertama kadar fenol antara perlakuan ECR dan EC tidak berbeda nyata, sedangkan antara perlakuan $\mathrm{ER}$ dan $\mathrm{K}$ berbeda nyata. Nilai terendah kadar fenol pada fermentasi tahap pertama ditemukan pada perlakuan ECR kemudian diikuti berturut-turut oleh kapang tertentu (Doi et al., 1989a). Di sini terbukti bahwa kombinasi kapang mempunyai kemampuan yang lebih besar melakukan degradasi fenol menjadi produk turunannya.

\section{PERUBAHAN NILAI pH}

Sakakibara et al. (1990) melaporkan lebih dari $96 \%$ campuran flavour berasal dari fraksi asam lemah dan fraksi netral. Pada asam kuat aroma produk berbau 
"punget", sedangkan pada asam lemah menimbulkan aroma smoke-like. Timbulnya berbagai macam rasa pada produk arabushi terutama disebabkan oleh komponen dasar dari asap dan salah satu komponen asap yang sangat berpengaruh dari pengolahan arabushiadalah senyawa fenol.

Nilai pH katsuobushi setelah fermentasi tahap I untuk masing-masing perlakuan adalah perlakuan $\mathrm{K}$ sebesar 5,27; ER = 5,37; EC dan ECR sebesar 5,29 (Gambar 5). Pada fermentasi tahap II nilai pH semua perlakuan cenderung meningkat mendekati netral perlakuan EC dan ER tidak menunjukkan perbedaan nyata, tetapi dibandingkan dengan perlakuan kombinasi (ECR) terdapat perbedaan nyata. Pada Gambar 5 dapat dilihat perubahan nilai $\mathrm{pH}$ selama proses fermentasi.

\section{PERUBAHAN KANDUNGAN ASAM AMINO}

Pengujian kandungan asam amino dari arabushi dilakukan setelah difermentasikan selama tiga tahap Analisis asam amino dilakukan terhadap 24 jenis asam amino yang terdiri atas sembilan asam amino esensial dan 15 asam amino non-esensial. Asam amino

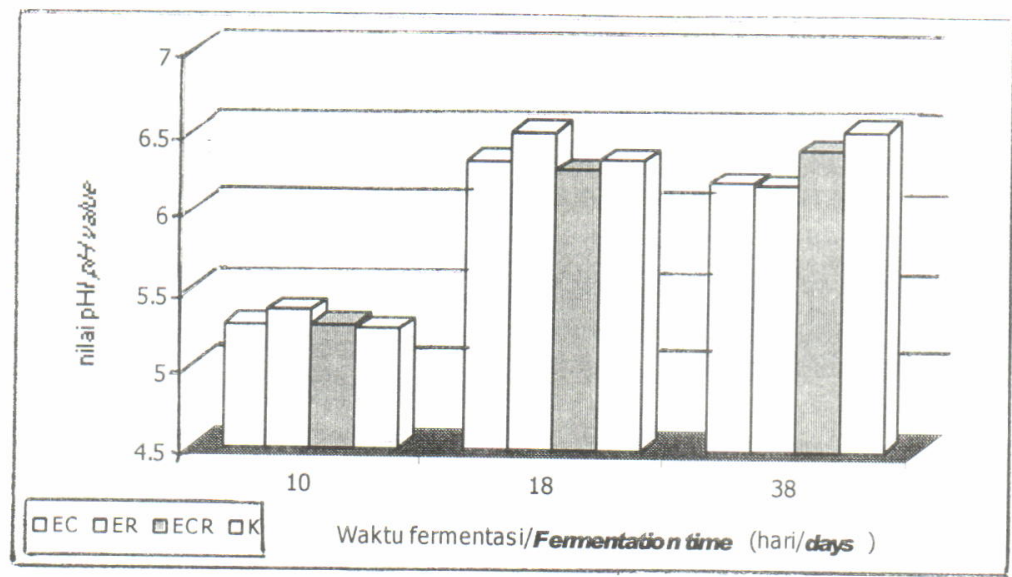

$\begin{aligned} E C= & \text { perlakuan inokulasi kapang } E \text {. chevalieri (innoculation of } E \text {. chevalieri) } \\ E R= & \text { perlakuan inokulasi kapang } E \text {. repens (innoculation of } E \text {. repens) } \\ \mathrm{ECR}= & \text { inokulasi kombinasi antara } E \text {. repens dan } E \text {. chevalieri (innoculation of combination between } E . \\ & \text { repens and } E \text {. chevalieri) } \\ \mathrm{K}= & \text { kontrol (control) }\end{aligned}$

Gambar 5. Perubahan nilai pH katsuobushi selama fermentasi

Figure 5. Fluctuation of $\mathrm{pH}$ value of katsuobushi during fermentation process

(asam lemah) dan tertinggi pada perlakuan ER sebesar 6,51; dan terendah pada perlakuan ECR = 6,26. Doi et al. (1989a; 1990) dan Sakakibara et al. (1990) melaporkan bahwa terbentuknya asam lemah pada produk katsuobushiadalah merupakan hasil dari degradasi fenol menjadi produk turunannya seperti asam propionat dan asam suksinat.

Pada fermentasi tahap III terjadi penurunan nilai $\mathrm{pH}$ pada perlakuan ER dan EC, sebaliknya nilai $\mathrm{pH}$ pada perlakuan $\mathrm{K}$ dan ECR cenderung meningkat (kearah netral) yang berarti masih terjadi degradasi fenol dan asam-asam amino, sedangkan pada perlakuan ER dan EC terjadi penurunan nilai $\mathrm{pH}$. Hal ini mungkin akibat adanya proses oksidasi dan hidrolisis lemak selama proses fermentasi yang menghasilkan berbagai jenis asam-asam organik. Jenis kapang dan kombinasinya serta tahapan fermentasi tidak berpengaruh terhadap perubahan nilai $\mathrm{pH}$ katsuobushi. Pada fermentasi tahap III antara triptofan yang merupakan asam amino essensial tidak terdeteksi setelah perebusan hal ini diduga selama perebusan terjadi kerusakan asam amino triptofan. Pada Tabel 1 dapat dilihat komposisi asam amino setiap perlakuan. Setelah fermentasi tahap III jumlah asam amino yang dapat terdeteksi pada masing-masing perlakuan berturut-turut adalah $\mathrm{K}$ sebesar 56,49\%; EC = 74,49\%; ECR $=90,07 \%$; dan $\mathrm{EC}=22,73 \%$. Fermentasi monokultur kurang mampu yang mendegradasi protein menjadi asam-asam amino. Ini terlihat bila arabushi difermentasikan dengan A. repens maka total protein yang dapat diubah menjadi asam-asam amino jauh lebih kecil dibandingkan dengan arabushi yang difermentasikan dengan A. chevalieri. Pada proses inokulasi kapang kombinasi, jumlah protein yang dapat diubah menjadi asam amino adalah sangat besar, tetapi bila fermentasi menggunakan kapang lebih dari dua jenis seperti pada kontrol, nilai asam amino yang diperoleh lebih kecil dibandingkan dengan kombinasi dua jenis kapang 
(ECR). Dari sembilan jenis asam amino esensial yang terdeteksi dan merupakan kelompok alipatik adalah valin, leusin, dan isoleusin; kelompok basa meliputi asam amino arginin, lisin, dan histidin; kelompok aromatik adalah fenilalanin dan tirosin. Sedangkan non-esensial yang bersifat asam adalah aspartat dan asam amino glutamat. Berdasarkan klasifikasi ini terbukti bahwa inokulasi campuran antara $E$. repens dan E. chevalieri mampu menguraikan protein menjadi asam-asam amino lebih banyak dibandingkan dengan perlakuan inokulasi secara monokultur. Jumlah asam glutamat yang terbentuk pada fermentasi alami (K) sebesar 2,3\%, sedangkan pada fermentasi monokultur (EC) sebesar 5,7\%, ER =0,5\%, dan kombinasi dua jenis kapang $(E C R)=6,7 \%$. Kemungkinan rendahnya konversi protein menjadi asam amino pada fermentasi tahap III pada perlakuan ER dan EC disebabkan selama fermentasi tahap I dan II telah terbentuk zat metabolit yang mengakibatkan pertumbuhan kapang terhambat pada proses fermentasi tahap selanjutnya.
Sedangkan pada perlakuan K mungkin telah terjadi kompetisi antar kapang sehingga konversi protein menjadi asam-asam amino sedikit terhambat. Sebaliknya pada ECR kemungkinan kapang yang tumbuh pada tahap fermentasi pertama telah memberikan kondisi yang lebih baik untuk kapang yang ditumbuhkan pada proses fermentasi selanjutnya.

\section{PERUBAHAN NILAI ORGANOLEPTIK}

Katsuobushiyang dihasilkan diuji aroma, rasa dan penerimaan umum pada setiap akhir fermentasi. Hasil pengujian membuktikan bahwa waktu fermentasi dan jenis kapang yang diinokulasikan berpengaruh terhadap nilai aroma, rasa, dan penerimaan umum. Nilai aroma, rasa, dan penerimaan umum cenderung menurun dengan semakin lamanya waktu fermentasi. Nilai tertinggi untuk aroma di antara perlakuan ditemukan pada perlakuan kombinasi inokulasi kapang yaitu perlakuan ECR, kemudian diikuti oleh

Tabel 1. Profil asam amino katsuobushiyang telah difermentasikan secara alami, monokultur, dan dikultur setelah fermentasi tiga tahap

Table 1. Amino acids profile of natural, monoculture, and diculture fermentation of katsuobushi after three steps of fermentation

\begin{tabular}{|c|c|c|c|c|c|c|}
\hline \multirow{2}{*}{$\begin{array}{l}\text { Jenis asam amino } \\
\text { Type of amino acids }\end{array}$} & \multicolumn{6}{|c|}{ Perlakuan (Treatments) } \\
\hline & $\begin{array}{l}\text { Rebus } \\
\text { Boiled }\end{array}$ & Arabushi & $\mathbf{K}^{\star *}$ & $\mathrm{EC}^{\star \star}$ & $\mathrm{ECR}^{\star *}$ & $\mathrm{ER}^{* *}$ \\
\hline Aspartat (Aspartate) & 2.24 & 0.6 & 6.11 & 7.77 & 7.65 & 0.75 \\
\hline Serin (Serine) & 1.1 & 0.34 & 2.27 & 3.28 & 4.39 & 0.33 \\
\hline Glutamat (Glutamate) & 5.73 & 1.3 & 2.34 & 5.66 & 6.71 & 0.53 \\
\hline Glisin (Glysine) & 1.04 & 0.26 & 2.19 & 3.62 & 3.94 & 0.39 \\
\hline Alanin (Alanine) & 2.24 & 0.36 & 3.07 & 5.42 & 5.4 & 0.74 \\
\hline Valin (Valine) & 1.82 & 0.36 & 3.74 & 3.66 & 4.64 & 0.89 \\
\hline Metionin (Methionine) & 1.05 & 0.13 & 2.22 & 3.55 & 5.2 & 3.41 \\
\hline Isoleusin (Isoleusine) & 1.42 & 0.37 & 4.02 & 3.65 & 5.15 & 2.4 \\
\hline Leusin (Leusine) & $\operatorname{ttd}$ & ttd & 4.96 & 4.17 & 5.43 & 1.03 \\
\hline Tirosin (Tyrosine) & 1.18 & 0.37 & 2.69 & 4.78 & 6.79 & 0.96 \\
\hline Fenilalanin (Phenilalanine) & 1.37 & 0.28 & 2.46 & 5.82 & 7.21 & 0.36 \\
\hline Histidin (Histidine) & 1.85 & 0.87 & 6.6 & 5.15 & 7.67 & 3.73 \\
\hline Lisin (Lysine) & 2.36 & 0.71 & 10.01 & 7.91 & 7.55 & 2.59 \\
\hline Arginin (Arginine) & 1.75 & 0.72 & 3.81 & 3.66 & 5.55 & 4.01 \\
\hline Threonin (Threonine) & $\mathrm{ttd}$ & ttd & ttd & 6.39 & 6.77 & 0.62 \\
\hline Jumlah (Total) & 25.15 & 6.67 & 56.49 & 74.49 & 90.05 & 22.74 \\
\hline
\end{tabular}

** = difermentasikan sebanyak tiga kali (fermented three times)

$\mathrm{K}=$ Kontrol (Control); $\mathrm{EC}=$ arabushi diinokulasi dengan $A$. chevalieri (arabushi was inoculated with $\boldsymbol{A}$. chevalieri); $E C R=$ arabushi dinokulasi dengan kombinasi kapang antara $A$. chevalieri dan $A$. repens (arabushi was inoculated with combination between $\boldsymbol{A}$. chevalieri and $\boldsymbol{A}$. repen); ER = arabushi diinokulasi dengan kapang $A$. repens (arabushi was inoculated with $\boldsymbol{A}$. repens), ttd = tidak terdeteksi (undetected) 
perlakuan K, ER, dan terakhir perlakuan EC. Sedangkan untuk nilai rasa berturut-turut adalah perlakuan ECR, ER, EC, dan perlakuan kontrol (K) Pada Tabel 2 dapat dilihat perubahan nilai aroma, rasa dan penerimaan umum katsuobushi.

Aroma katsuobushi sangat dipengaruhi oleh senyawa fenolik dan kemampuan kapang melakukan degradasi dan O-metilasi selama proses fermentasi (Doi et al., 1989b), sedangkan Toth \& Potthast (1984) menyatakan bahwa senyawa fenol, karbonil (sebagai asetaldehid), dan asam (sebagai asam asetat) merupakan faktor utama yang bertanggung jawab terhadap flavor daging asap. Lebih lanjut dinyatakan sebagian besar komposisi dari ketiga senyawa tersebut bersifat volatil. Namun demikian yang berkorelasi positif terhadap pembentukan aroma dan rasa ikan asap adalah kadar fenol.

Perubahan nilai rasa katsuobushi disebabkan senyawa-senyawa pembentuk flavor yang bersifat volatil diantaranya asam amino, nukleotida, dan asam organik (Sakakibara et al., 1990). Diduga L-asam amino glutamat, asam ibetoniat, dan trikoloniat mempunyai potensi besar dalam pembentukan flavor produk. Di samping ketiga jenis senyawa tersebut guanosin 5'-monofosfat (5'-GMP), inosin 5'monofosfat (5'-IMP), dan xantosin 5'monofosfat (5'-XMP) juga berperanan penting dalam mengubah rasa dalam produk. Terbukti bahwa peranan inokulasi secara monokultur, dan dikultur kapang selama proses fermentasi arabushi menjadi katsuobushi berpengaruh terhadap pembentukan aroma dan rasa katsuobushi yang dihasilkan.

\section{KESIMPULAN}

Perlakuan inokulasi kapang pada permukaan arabushi yang dilakukan secara monokultur dan dikultur, serta waktu fermentasi berpengaruh terhadap perubahan kadar air, nilai $\mathrm{pH}, \mathrm{a}_{w}$, kadar fenol, dan kemampuan mendegradasi protein menjadi asam-asam amino. Hasil uji organoleptik aroma dan rasa menunjukkan terjadinya penurunan nilai selama fermentasi. Pengamatan hingga fermentasi tahap tiga memperlihatkan bahwa kemampuan degradasi protein menjadi asam-asam amino lebih besar bila proses fermentasi arabushi menggunakan kombinasi kapang E. repens dan E. chevalieri. Ditinjau dari kemampuan mendegradasi protein menjadi asam-asam amino, maka perlakuan terbaik adalah perlakuan kombinasi antara E. repens dan E. chevalieri.

\section{DAFTAR PUSTAKA}

AOAC., 1980. Official Methods of Analysis of the Assosiation of Official Analitycal Chemist. Benjamin Franklin Station, Washington D.C. p. 547 and p. 669.

Basmal, J., N. Indriati., S. Nasran, dan N. Hak. 1998. Penelitian pendahuluan pengolahan katsuobushi cakalang (Katsuwonus pelamis) secara alami. Prosiding Simposium Perikanan Indonesia II. Ujung Pandang 2-3 Desember 1997. Pusat Penelitian dan Pengembangan Perikanan, Jakarta. p. 377-385.

Tabel2. Perubahan nilai aroma, rasa, dan penerimaan umum filtrat katsuobushi setiap akhir fermentas Table 2. Change of flavour, taste, and general acceptance of katsuobushi filtrate at the end of fermentation

\begin{tabular}{|c|c|c|c|c|c|c|c|c|c|c|c|c|c|c|c|}
\hline \multirow{2}{*}{$\begin{array}{l}\text { Perlakuan } \\
\text { Treatment }\end{array}$} & \multicolumn{5}{|c|}{ Aroma (Flavor) } & \multicolumn{5}{|c|}{ Rasa (Taste) } & \multicolumn{5}{|c|}{ P. umum (G. acceptance) } \\
\hline & $\mathrm{Ft} 1$ & $\mathrm{Ft} 2$ & $\mathrm{Ft} 3$ & $\begin{array}{c}\text { Rataan } \\
\text { Avg. }\end{array}$ & Stdev & $\mathrm{Ft} 1$ & $\mathrm{Ft} 2$ & Ft3 & $\begin{array}{c}\text { Rataan } \\
\text { Avg. }\end{array}$ & Stder & $\mathrm{Ft} 1$ & Ft2 & Ft3 & $\begin{array}{c}\text { Rataan } \\
\text { Avg. }\end{array}$ & Stdev \\
\hline EC & 3.82 & 3.00 & 3.27 & 3.27 & 0.47 & 3.89 & 3.75 & 3.55 & 3.73 & 0.17 & 3.55 & 4.10 & 2.90 & 3.52 & 0.60 \\
\hline ER & 3.50 & 3.47 & 3.29 & 3.29 & 0.34 & 4.20 & 3.50 & 3.60 & 3.77 & 0.38 & 3.92 & 4.00 & 3.20 & 3.71 & 0.44 \\
\hline ECR & 4.20 & 3.38 & 3.66 & 3.66 & 0.47 & 4.40 & 3.90 & 3.75 & 4.02 & 0.34 & 4.00 & 3.55 & 3.05 & 3.53 & 0.48 \\
\hline K & 3.60 & 3.15 & 3.32 & 3.32 & 0.25 & 4.20 & 3.75 & 3.20 & 3.72 & 0.50 & 3.75 & 3.40 & 3.05 & 3.40 & 0.35 \\
\hline $\begin{array}{l}\text { Rataan } \\
\text { Average }\end{array}$ & 3.78 & 3.25 & 3.38 & 3.38 & 0.35 & 4.17 & 3.73 & 3.53 & 3.81 & 0.33 & 3.80 & 3.76 & 3.05 & 3.54 & 0.42 \\
\hline Stdev & 0.31 & 0.21 & 0.18 & 0.18 & - & 0.21 & 0.17 & 0.23 & 0.14 & - & 0.2 & 0.34 & 0.12 & 0.13 & - \\
\hline
\end{tabular}

Pt1-Ft III = Waktu fermentasi (Steps of Fermentation time); Arg = rata-rata(average); Stdev = standar deviasi (standart deviation); EC = perlakuan inokulasi kapang E. chevalieri (Inoculation of E. chevalieri); $\mathrm{ER}=$ perlakuan inokulasi kapang $E$. repens (Inoculation of $E$. repens); ECR = perlakuan inokulasi kombinasi antara $E$. chevalieri dan E. repens (Inoculated combination between E. chevalieri and $E$. 
Doi M., M. Matsui, Y. Shuto, and Y. Kinoshita, 1989a Degradation and o-methylation of phenols among volatile flavor compounds of dried bonito (katsuobushi) by Aspergillus species. Agric. Biol. Chem. 53(4):1051-1055.

1989b. O-methylation of phenols by Aspergillus repens MA0197. Agric. Biol. Chem. 53(11):3031-3032.

1990. Biological isomerization of cyclohexanols by Aspergillus repens MA0197. Agric Biol. Chem 54(5) 1177-1181.

Giyatmi, 1998. Isolasi dan Identifikasi Kapang pada Pembuatan Ikan Kayu (Katsuobushi) Cakalang (Katsuwonus pelamis L.) dengan Fermentasi Alami. Thesis, Program Pasca Sarjana, Institut Pertanian Bogor.

Hanafiah, T.A.R., B.I. Winarno, dan H. Marasabessy. 1984. Pengamatan pada proses pembuatan ikan kayu cakalang (Katsuwonus pelamis). Journal Pen. Pascapanen Perikanan p.15-22.

Nasran, S., dan H.E. Irianto. 1987. Penelitian pengolahan ikan kayu. Jurnal Pen. Pascapanen Perikanan 58:31-38
Pitt. J.I. and A.D. Hocking. 1985. Fungi and Food Spoilage. Text book. Academic Press. Tokyo. p.269-274.

Sakakibara, H., M. Hosokawa, I. Yajima, and K. Hayashi. 1990. Flavor constituents of dried bonito (katsuobushi). Food Review International. 6(4):553-572.

Samson, R.A., E.S. Hocking, J. C. Frisvad, and 0. Filterborg. 1995. Introduction to Food-Bome Fungi. 4th edition. Central Bureau voor Schimmelcultures. Netherlands. p.235-289.

Sej van Eys. 1983. Katsuobushi - a Japanese speciality. Infofish Marketing Digest No. 2 p.23-27.

Tanikawa, E., T. Kotohiro, and M. Akiba. M., 1985. Marine Product in Japan, Koseisha Okseikaku. Co. Ltd. Tokyo. p.246-252.

Toth, L. dan K. Potthast, 1984. Chemical aspects of the smoking of meat and meat products, C.O. Chichester, E.M. Mrak, and B.S. Schweigert, eds. Advances in Food Research. Academic Press, Inc., Orlando.

Wheaton, F.W dan T.B. Lawson. 1985. Quality Changes in Aquatic Food Products. Processing Aquatic Food Products. A. Wiley-Interscience Publication p.225-272. 